\title{
Variability in the structure of epiphytic microalgae assemblages on the leaves of Posidonia oceanica in relation to human disturbance in a meadow off Tunisia
}

\author{
Lotfi Mabrouk ${ }^{1,2}$, Mounir Ben Brahim ${ }^{1,2}$, Asma Hamza ${ }^{2}$, Mabrouka Mahfoudhi ${ }^{2}$, \\ Med-Najmeddine Bradai ${ }^{2}$ \\ ${ }^{1}$ Faculté des Sciences de Sfax, Route de la Soukra km 4, BP 802-3038 Sfax, Tunisia. E-mail: lotfi2328@yahoo.fr \\ ${ }^{2}$ Institut National des Sciences et Technologies de la Mer, centre de Sfax- BP 1035-CP 3018 Sfax, Tunisia.
}

\begin{abstract}
Summary: We investigated the impact of sewage discharge on Posidonia oceanica meadows in Mahdia, eastern Tunisia. We specifically addressed changes in biometric plant parameters and epiphytic microalgae composition on leaves caused by this anthropogenic interference. A hierarchical sampling design was used to compare epiphytic microalgae structure between one disturbed and two control stations. Samples were collected by SCUBA diving at $8 \mathrm{~m}$ depth in August 2009 . A total of 58 microalgae taxa were identified on leaves. At the disturbed station, leaf length, leaf surface area and the leaf area index decreased, whereas epiphytic dinoflagellate abundances increased compared with the control stations, with more Prorocentrales, Protoperidiniales and potentially toxic species on leaves of the disturbed station. Moderate nutrient enrichment (mainly $\mathrm{Si}(\mathrm{OH})_{4}$ and $\mathrm{NH}_{4}{ }^{+}$) and low water transparency at the disturbed station were associated with the increased abundances of some dinoflagellate species.
\end{abstract}

Keywords: epiphytic microalgae; sewage disturbance; spatial variability; Posidonia oceanica.

Variabilidad en la estructura de las comunidades de microalgas epífitas en las hojas de Posidonia oceanica en respuesta a las perturbaciones humanas en una pradera de Túnez

Resumen: Se ha investigado el impacto de los vertidos de aguas residuales en praderas de Posidonia oceanica situadas en Mahdia (Este de Túnez). Se han estudiado los cambios en los parámetros biométricos de la planta y la composición de las microalgas epífitas en las hojas causadas por esta interferencia antrópica. Se ha utilizado un diseño de muestreo jerárquico para comparar las microalgas epífitas entre la estación perturbada y dos estaciones control. Las muestras se recolectaron en buceo autónomo a $8 \mathrm{~m}$ de profundidad en Agosto de 2009. La longitud, el área y el índice de área de las hojas era inferior en la estación perturbada mientras que las abundancias de los dinoflagelados epífitos eran mayores en las estaciones control, con más Prorocentrales, Protoperidiniales y otras especies tóxicas potenciales en las hojas de la estación perturbada. Un ligero aumento de nutrientes en la estación perturbada (sobre todo $\mathrm{Si}(\mathrm{OH})_{4} \mathrm{y} \mathrm{NH}_{4}^{+}$) y una menor transparencia del agua iba asociada a un aumento en la abundancia de algunas especies de dinoflageladas.

Palabras clave: microalgas epífitas; aguas residuales; variabilidad espacial; Posidonia oceanica.

Citation/Como citar este artículo: Mabrouk L., Ben Brahim M., Hamza A., Mahfoudhi M., Bradai M.N. 2014. Variability in the structure of epiphytic microalgae assemblages on the leaves of Posidonia oceanica in relation to human disturbance in a meadow off Tunisia. Sci. Mar. 78(1): 27-39. doi: http://dx.doi.org/10.3989/scimar.03939.06A

Editor: E. Ballesteros.

Received: August 21, 2013. Accepted: November 12, 2013. Published: February 24, 2014.

Copyright: (C) 2014 CSIC. This is an open-access article distributed under the Creative Commons Attribution-Non Commercial Lisence (by-nc) Spain 3.0.

\section{INTRODUCTION}

Seagrass systems are characterized by high biodiversity. Their leaves offer substrata suitable for settlement and growth of a number of micro- and macro- colonists that form stratified assemblages characterized by a high diversity of species (Mazzella et al. 1989). The most abundant and diverse epiphytic organisms on seagrasses are algae. They range from unicellular diatoms and dinoflagellates to large macrophytes. Epiphytes contribute to the primary production of the seagrass, formation of sediment (Frankovich and Zieman 1994) 
and nutrient cycling (Borowitzka et al. 2006) and they are a direct as well as an indirect food source for many animal species (Gambi et al. 1992).

The sensitivity of Posidonia oceanica (L.) Delile to human impacts on ecosystems is an interesting biological indicator of these impacts in the coastal environment (Pergent et al. 1995). Montefalcone (2009) reviewed the use of $P$. oceanica as a bioindicator and found three levels of investigation: the "individual" level, in which the phenology of the plant (especially leaf biometry) provides information about its status and growth condition (Marbà et al. 2006); the "population" level, in which the structure (e.g. density and/or cover) and morphology of the meadow represent characteristic imprints of environmental conditions (Montefalcone et al. 2008); the "community" level, in which the associated flora and fauna (especially epiphytes) are similarly susceptible to environmental alterations (Cancemi et al. 2003). Seagrass epiphytes are known to be even more sensitive to environmental changes than the plant hosts (Nesti et al. 2009). Epiphytic microalgae composition, in particular, is influenced by abiotic factors such as temperature (Aligizaki and Nikolaidis 2006; Turki 2005), light, salinity, and nutrient availability (Armitage et al. 2006) and biotic factors such as grazing (Mazzella and Russo 1989), shoot length, density and morphology of the host plant (Sirota and Hovel 2006, Chung and Lee 2008, Mabrouk et al. 2011). Nutrient over-enrichment caused by anthropogenic activities has been associated with the shift of the structure of microepiphytic assemblages (Armitage et al. 2006) and the decline of seagrass (Green and Short 2003, Orth et al. 2006, Ben Brahim et al. 2010). For example, a reduction of leaf growth and a decrease in shoot density were observed around a sewage outfall (Pergent-Martini 1994) as a consequence of epiphyte overgrowth (Cambridge et al. 1986).

It is widely known that the distribution of epiphytic assemblages of $P$. oceanica both on leaves (Mazzella et al. 1989) and rhizomes (Piazzi et al. 2004; Balata et al. 2008) can change, but few studies analysing changes in epiphyte assemblages on leaves of $P$. oceanica in Tunisia has been published (Ben Brahim et al. 2010, Mabrouk et al. 2013), and to our knowledge no studies on microepiphytes have been conducted up to now. Many authors have bemoaned the lack of data in some Mediterranean regions, particularly North Africa (Ruiz et al. 2009). It is therefore of importance to undertake a study of the effects of urban pressure on $P$. oceanica dynamics under the impact of human activities vs. control conditions. We analysed, for the first time in the east of Tunisia (Mahdia), the structure and patterns of spatial variability of leaf epiphytic microalgae assemblages and tested their relationships with the degree of anthropogenic disturbance. We analysed the biometric parameters of Posidonia oceanica and its leaf microalgal epiphytes, looking at nutrient enrichment from sewage discharges as a cause for observed changes.

We attempted to answer the questions 1) how vulnerable are the biometric parameters of $P$. oceanica to these environmental pressures? and 2) which members of the epiphytic microalgae community should be con- sidered as the most sensitive species? We thus compared plant biometric parameters and epiphytic microalgae assemblages of Posidonia oceanica between a station exposed to urban and industrial effluents, and two control stations, and examined their variability at spatial scales using a hierarchical sampling design (Underwood 1992).

\section{MATERIALS AND METHODS}

\section{Study area}

The study was carried out on the littoral close to Mahdia, eastern Tunisia in the southern Mediterranean Sea. The climate is semiarid (average precipitation, $350 \mathrm{~mm}$ year $^{-1}$ ) and sunny with strong northerly winds. Since 1993, this coastal area has been exposed to the discharge of sewage from domestic and industrial factories (textile, engineering, metallurgy, electronics, chemistry, food, ceramics and glass industries).

\section{Sampling and data collection}

Three sampling stations $2 \mathrm{~km}$ distant from each other were chosen in August 2009 when the P. oceanica microepiphytic community reached its maximum abundances and diversity (Aligizaki and Nikolaidis 2006, Turki 2005, Mabrouk et al. 2011).

The depth at all stations was $8 \mathrm{~m}$ and temperature and salinity ranges were $27-30^{\circ} \mathrm{C}$ and $38-40$, respectively. The station disturbed by sewage discharge, Ben Ghayadha $\left(35^{\circ} 29^{\prime} 14^{\prime}\right.$ 'N, $11^{\circ} 03^{\prime} 38^{\prime}$ 'E, labelled D hereafter) is located about $200 \mathrm{~m}$ from the outfall. Two other sites, Sidi Salem (35 $30^{\circ}$ ' $12^{\prime}$ N , $11^{\circ} 04^{\prime} 25^{\prime}$ 'E) and Cap Africa $\left(35^{\circ} 35^{\prime} 43^{\prime}\right.$ 'N, $11^{\circ} 05^{\prime} 42^{\prime}$ 'E) were selected as control stations $(\mathrm{C} 1, \mathrm{C} 2)$, located north of the disturbed area (Fig. 1). In accordance with the hierarchical sampling design, three sites (500 m apart) were chosen randomly at each station; and at each site, three random replicate quadrates $\left(1600 \mathrm{~cm}^{2}\right.$ large and about $10 \mathrm{~m}$ apart) were sampled. Within each quadrat, all shoots were randomly sampled and preserved in $4 \%$ formalin seawater for laboratory work.

At each station, three water samples were collected for nutrient analyses. Samples were taken using a 125$\mathrm{ml}$ plastic bottle previously treated with hydrochloric acid, held directly above the $P$. oceanica stands. On reaching the surface, the samples were shaken and then filtered with a $0.45-\mu \mathrm{m}$ filter (cellulose acetate, 17 $\mathrm{mm}$ ). Samples were frozen in liquid nitrogen for transportation to the laboratory, where concentrations of $\mathrm{NO}_{2}^{-}, \mathrm{NO}_{3}{ }^{-}, \mathrm{NH}_{4}{ }^{+}, \mathrm{PO}_{4}^{-}, \mathrm{Si}(\mathrm{OH})_{4}$, total dissolved nitrogen (TN) and total dissolved phosphorus (TP) were measured following standard colorimetric techniques (Grasshoff et al. 1983). Water transparency was measured three times, before sampling, at each site using a Secchi disc, with measurements made at about noon.

The density of $P$. oceanica shoots was estimated from 27 replicates present within $1600 \mathrm{~cm}^{2}$ quadrats inside each meadow.

To detach the microepiphytic communities, from each quadrat leaves were detached from their sheet and 


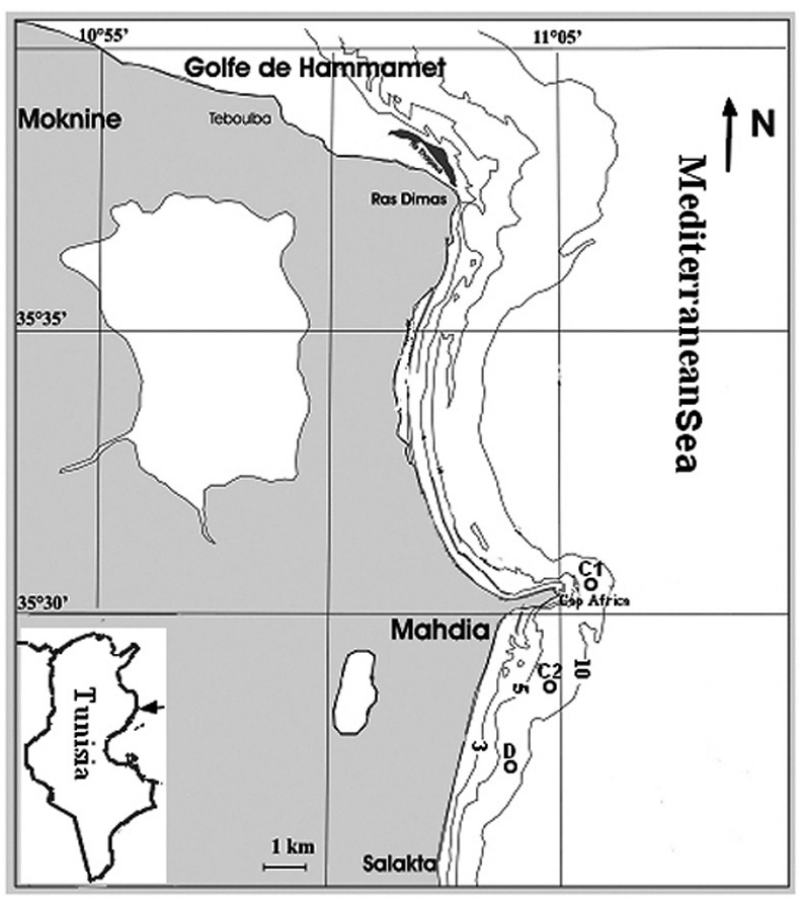

Fig.1. Map of the study area, showing the sampling stations: $\mathrm{C} 1$ and $\mathrm{C} 2$, control stations; $\mathrm{D}$, disturbed station.

weighed to $100 \mathrm{~g}$ with an electronic precision balance (Turki 2005). Weighed leaves were placed in plastic bottles, and washed with aged seawater (left at room temperature for several months) to remove loosely attached epiphytes (Aligizaki and Nikolaidis 2006); then the remaining epiphytic material was scraped with a razor blade dragged at a right angle against the leaf along the length (Kendrick and Lavery 2001). The scraped material was washed through a $500-\mu \mathrm{m}$ sieve to separate larger epiphyte fragments from the microepiphytes. Fleshy epiphytes on the sieve were separated by hand from the periphyton, which consisted of the remaining material on the sieve (calcareous encrusting algae) and the smaller periphyton which had passed through the sieve (Jernakoff and Nielsen 1997, Kendrick and Lavery 2001). The filtered material was then passed through 250- and 100- $\mu \mathrm{m}$ mesh sieves to remove large particles, fixed with Lugol's solution and finally preserved in $5 \%$ formalin; its volume (V) was noted. All filtered materials were kept in the dark at ambient temperature until microscopic observation. Settling long glass tubes used for sedimentation procedure were 2 $\mathrm{cm}$ wide by $21 \mathrm{~cm}$ long and had a base plate containing a coverslip onto which the algae settled. To mix the sample, the bottle was gently tilted back and forth 10 times before pouring. A 50-ml sub-sample was poured into the settling chamber and left to settle for $24 \mathrm{~h}$. Subsamples were examined in an inverted microscope at medium $(\times 200)$ magnification by scanning the entire surface of the settling chamber to enumerate epiphytic microalgae (Utermöhl, 1958; Sournia, 1978). The total number of microalgae individuals $(\mathrm{N})$ contained in $100 \mathrm{~g}$ of fresh weight Posidonia [expressed as number of individuals per $100 \mathrm{~g}$ of fresh weight of Posidonia (fw)] is obtained by the conversion $\mathrm{N}=(\mathrm{n} \times \mathrm{V}) / \mathrm{v}$, where $\mathrm{n}=$ number of individuals counted, $\mathrm{V}=$ volume of the filtered material and $\mathrm{v}=$ volume of the sedimentation chamber $(50 \mathrm{ml})$. The identified taxa were divided into groups (diatoms, dinoflagellates, cyanobacteria).

Among the remaining sample of each quadrat, 60 shoots were taken and leaves were removed in distichous order of insertion and separated into the various categories defined by Giraud (1979). For each shoot, the following leaf traits were scored: (1) total number of standing leaves; (2) total number and (3) length of adult and intermediate leaves and (4) leaf width. Leaf area index (LAI, $\mathrm{m}^{2} \mathrm{~m}^{-2}$ ) was determined as product of leaf surface area (total leaf length $\times$ mean leaf width, $\mathrm{cm}^{2} /$ shoot) and shoot density.

\section{Data analysis}

Data were tested for normality using the Kolmogorov-Smirnov test (Zar 1999) and for heteroscedasticity using Cochran's $\mathrm{C}$ test, and transformed if necessary (Underwood 1992).

Relationships between epiphytic species abundance and abiotic parameters were examined using the RELATE procedure in PRIMER. RELATE is the equivalent of a nonparametric Mantel test (Somerfield et al. 2002). It assesses the degree of correspondence between matrices and, via a randomization test, provides a measure of statistical significance of the relationship (Clarke and Warwick 2001). The matrix of similarities between epiphytic species abundance (based on BrayCurtis coefficient from $\log (\mathrm{x}+1)$-transformed data) was compared with a matrix of the similarity between abiotic parameters (based on Euclidean distance from $\log (x+1)$-transformed data). The significance of any correlation between matrices was assessed with a randomization test.

Analysis of similarity (ANOSIM) randomization tests were used to test for differences in community composition (with presence-/absence-transformed data) and for differences in species abundance (with $\log (\mathrm{x}+1)$-transformed data) between control and disturbed stations (Clarke 1993). Differences found using ANOSIM were followed up using similarity percentage (SIMPER) analysis to identify which species primarily accounted for the observed differences between sites. SIMPER generates a ranking of the species responsible for the significant differences. These analyses used a matrix composed of Bray-Curtis similarity coefficient generated with $\log (\mathrm{x}+1)$-transformed species abundance data.

Analysis of variance (ANOVA) was used to test the hypothesis that the abundance of each group of taxa differed between disturbed and reference stations. As is common in studies of impact, there was only one disturbed station [chosen using previous inspection of $P$. oceanica meadow (Mabrouk et al. 2009) and its macroepiphytes (Mabrouk et al. 2013)] and the analyses were asymmetrical (Underwood 1992). The sums of squares of the factor station were divided into two components: the contrast 'disturbed vs control' and the variability among controls. Sites were nested within stations and quadrats were nested within sites. All factors (stations, sites, quadrats and the contrast 'disturbed 

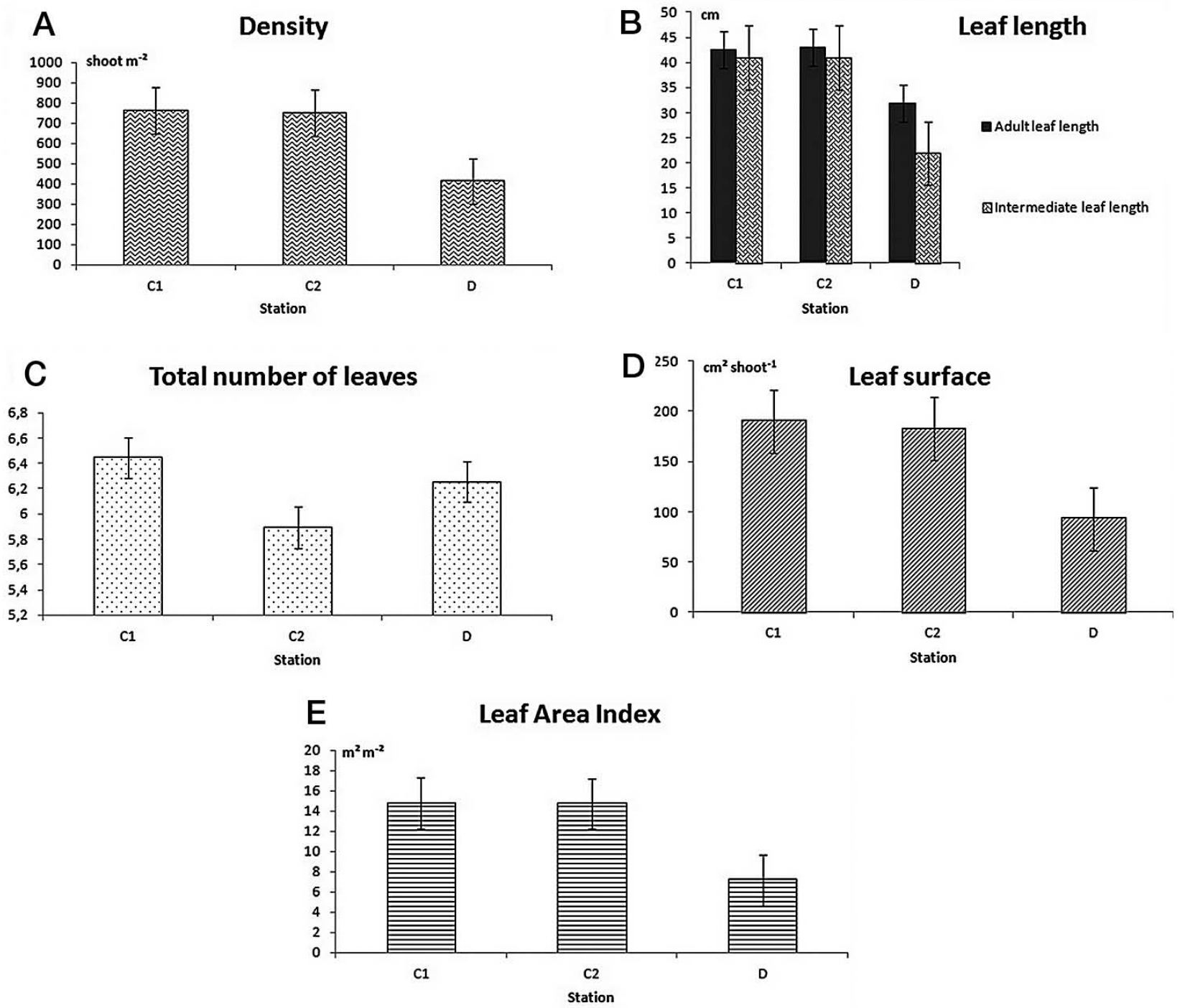

Fig. 2. - Mean \pm sd of biometric parameters of Posidonia oceanica at sampling stations.

vs control') were fixed. The same design was employed for the biometric parameters of $P$. oceanica, nutrient concentrations and transparency. A Tukey HDS test was applied for multiple comparisons of means.

Canonical correspondence analysis (CCA), a direct gradient analysis technique (ter Braak and Verdonschot 1995), was used to investigate the relationship between epiphytic species and physicochemical parameters. Epiphytic microalgae abundance data were $\log (x+1)$ transformed prior to the analysis in order to stabilize the variance and to optimize the signal-to-noise ratio in the data set. Down-weighting for rare species was performed. Forward selection and associated Monte Carlo permutation tests (499 unrestricted permutations) were used to identify a subset of environmental variables that contributed mostly to the epiphyte abundances in the data set. The environmental parameters which best described the distribution of the species data were a priori identified by forward selection (ter Braak and Verdonschot 1995). Only significant environmental variables are included in the model. CANOCO 4.5 (Scientia Software) software was used.

\section{RESULTS}

The disturbed station exhibited quite higher concentrations of nitrite, nitrate, ammonium, phosphate and $\mathrm{Si}(\mathrm{OH})_{4}$, TP and TN. Water transparency was higher at the control stations (Table 1). The lowest shoot density, adult and intermediate leaf length, leaf surface, leaf area index and leaf biomass were recorded in disturbed station D (Fig. 2). ANOVA analysis showed that most of biometric parameters (shoot density, leaf length, leaf surface and leaf area index) of $P$. oceanica differed between control and disturbed stations (Table 2).

The RELATE procedure in PRIMER software reveals significant correlations between physicochemical and biometric parameters and abundance of microepiphytes $(\mathrm{R}=0.214, \mathrm{p}=0.007)$.

For epiphytic microalgae on the leaves of $P$. oceanica, 58 species were counted, including 52 at the control stations and 44 at the disturbed station (Appendix 1). ANOSIM of epiphytic microalgae species abundances $\log (\mathrm{x}+1)$-transformed showed significant differences $(\mathrm{R}=0.591 ; \mathrm{p}=0.01)$ between the control sta- 
Table 1. - The mean \pm SD values of physical and chemical variables measured at all stations during the sampling period. Difference between control stations (C) and disturbed station (D) was tested by asymmetrical ANOVA. ***, P<0.001; Tr, transparency.

\begin{tabular}{|c|c|c|c|c|c|c|c|}
\hline \multirow[b]{2}{*}{ Variables } & \multirow[b]{2}{*}{ unit } & \multirow[b]{2}{*}{$\mathrm{N}$} & \multirow{2}{*}{\multicolumn{2}{|c|}{$\begin{array}{c}\text { Station }(\text { mean } \pm \text { sd }) \\
\text { C2 }\end{array}$}} & \multirow[b]{2}{*}{$\mathrm{D}$} & \multicolumn{2}{|c|}{ ANOVA (C vs. D) } \\
\hline & & & & & & $\mathrm{F}_{(1 ; 26)}$ & Tukey test \\
\hline $\operatorname{Tr}$ & $\mathrm{cm}$ & 27 & $431.8 \pm 9.22$ & $419.1 \pm 9.46$ & $111.47 \pm 13.51$ & $558.824 * * *$ & $\mathrm{C}>\mathrm{D}$ \\
\hline $\mathrm{NO}_{2}^{-}$ & $\mu \mathrm{mol} \mathrm{1} 1^{-1}$ & 27 & $0.339 \pm 0.013$ & $0.384 \pm 0.002$ & $0.821 \pm 0.015$ & $2404.878 * * *$ & $\mathrm{D}>\mathrm{C}$ \\
\hline $\mathrm{NO}_{3}^{-}$ & $\mu \mathrm{mol} \mathrm{1} 1^{-1}$ & 27 & $2.312 \pm 0.061$ & $3.172 \pm 0.021$ & $5.917 \pm 0.014$ & $443.685^{* * *}$ & $\mathrm{D}>\mathrm{C}$ \\
\hline $\mathrm{NH}_{4}^{+}$ & umol 1 $1^{-1}$ & 27 & $10.556 \pm 0.117$ & $4.176 \pm 0.066$ & $13.832 \pm 0.145$ & $29.361 * * *$ & $\mathrm{D}>\mathrm{C}$ \\
\hline $\mathrm{PO}_{4}^{3-}$ & $\mu \mathrm{mol} \mathrm{l}^{-1}$ & 27 & $0.597 \pm 0.021$ & $0.684 \pm 0.018$ & $0.950 \pm 0.022$ & $144.008 * * *$ & $\mathrm{D}>\mathrm{C}$ \\
\hline $\mathrm{Si}(\mathrm{OH})_{4}$ & $\mu \mathrm{mol} \mathrm{1} 1^{-1}$ & 27 & $0.946 \pm 0.017$ & $2.081 \pm 0.086$ & $3.548 \pm 0.113$ & $120.644 * * *$ & $\mathrm{D}>\mathrm{C}$ \\
\hline $\mathrm{TP}$ & umol 1 $1^{-1}$ & 27 & $3.917 \pm 0.107$ & $3.345 \pm 0.114$ & $5.487 \pm 0.103$ & $947.158 * * *$ & $\mathrm{D}>\mathrm{C}$ \\
\hline $\mathrm{TN}$ & $\mu \mathrm{mol} \mathrm{1} 1^{-1}$ & 27 & $22.355 \pm 0.293$ & $16.328 \pm 0.155$ & $24.643 \pm 0.328$ & $20.201 * * *$ & $\mathrm{D}>\mathrm{C}$ \\
\hline
\end{tabular}

Table 2. - ANOVA on phenological parameters of $P$. oceanica between controls and the disturbed station. St, station; si, site; qd, quadrate; C, control; D, disturded; res, residuals; ** $\mathrm{p}<0.01 ; * * * \mathrm{p}<0.001$

\begin{tabular}{|c|c|c|c|c|}
\hline Source & Df & MS & $\mathrm{F}$ test & Tukey test \\
\hline $\begin{array}{l}\text { Density ( } \text { (shoots } \mathrm{m}^{-2} \text { ) } \\
(\text { Cochran } \mathrm{C} \text { test } \mathrm{C}=0.27 \mathrm{p}=0.61 \mathrm{n} \text {. s.) } \\
\text { St } \\
\mathrm{C} \text { vs.D } \\
\text { among controls } \\
\text { si(St) } \\
\text { qd(si) } \\
\text { Res } \\
\text { Res (C vs.D) }\end{array}$ & $\begin{array}{c}2 \\
1 \\
1 \\
4 \\
6 \\
12 \\
25\end{array}$ & $\begin{array}{c}350554.62 \\
700454.630 \\
654.617 \\
8236.70 \\
2374.09 \\
4193.33 \\
5397.4\end{array}$ & $\begin{array}{c}83.60 * * * \\
171.98 * * * \\
0.140 \\
1.96 \\
0.57\end{array}$ & $\begin{array}{c}\mathrm{C} 1=\mathrm{C} 2>\mathrm{D} \\
\mathrm{C}>\mathrm{D} \\
\text { n.s. } \\
\text { n. s. } \\
\text { n.s. }\end{array}$ \\
\hline $\begin{array}{l}\text { Total number of leaves per shoot } \\
\text { (Cochran C test } \mathrm{C}=0.20 \mathrm{p}=0.62 \mathrm{n} \text {. s.) } \\
\text { St } \\
\text { C vs.D } \\
\text { among controls } \\
\text { si(St) } \\
\text { qd(si) } \\
\text { Res } \\
\text { Res (C vs.D) }\end{array}$ & $\begin{array}{c}2 \\
1 \\
1 \\
4 \\
6 \\
12 \\
25\end{array}$ & $\begin{array}{c}0.71 \\
0.034 \\
0.023 \\
0.13 \\
0.78 \\
0.70 \\
0.8\end{array}$ & $\begin{array}{c}1.00 \\
1.590 \\
0.760 \\
0.18 \\
1.10\end{array}$ & $\begin{array}{l}\text { n. s. } \\
\text { n. s. } \\
\text { n. s. } \\
\text { n. s. } \\
\text { n. s. }\end{array}$ \\
\hline $\begin{array}{l}\text { Adult leaf length }(\mathrm{cm}) \\
\text { (Cochran C test } \mathrm{C}=0.22 \mathrm{p}=0.79 \text { n. s.) } \\
\text { St } \\
\text { C vs.D } \\
\text { among controls } \\
\text { si(St) } \\
\text { qd(si) } \\
\text { Res } \\
\text { Res (C vs.D) }\end{array}$ & $\begin{array}{c}2 \\
1 \\
1 \\
4 \\
6 \\
12 \\
25\end{array}$ & $\begin{array}{c}356.15 \\
711.553 \\
0.748 \\
10.01 \\
19.06 \\
21.95 \\
24.32\end{array}$ & $\begin{array}{c}16.23 * * * \\
42.38 * * * \\
0,036 \\
0.46 \\
0.87\end{array}$ & $\begin{array}{c}\mathrm{C} 1=\mathrm{C} 2>\mathrm{D} \\
\mathrm{C}>\mathrm{D} \\
\text { n.s. } \\
\text { n.s. } \\
\text { n.s. }\end{array}$ \\
\hline $\begin{array}{l}\text { Intermediate leaf length }(\mathrm{cm}) \\
\text { (Cochran C test } \mathrm{C}=0.22 \mathrm{p}=0.90 \text { n. s.) } \\
\text { St } \\
\text { C vs.D } \\
\text { among controls } \\
\text { si(St) } \\
\text { qd(si) } \\
\text { Res } \\
\text { C vs.D } \\
\text { Res (C vs.D) }\end{array}$ & $\begin{array}{c}2 \\
1 \\
1 \\
4 \\
6 \\
12 \\
1 \\
25\end{array}$ & $\begin{array}{l}1090.83 \\
17,488 \\
1.3 \mathrm{E}-3 \\
4.52 \\
4.23 \\
3.11 \\
728.22 \\
4.39\end{array}$ & $\begin{array}{c}351.03^{* * *} \\
751.05^{* * *} \\
0.001 \\
1.45 \\
1.36 \\
165.76^{* * *}\end{array}$ & $\begin{array}{l}\mathrm{C} 1=\mathrm{C} 2>\mathrm{D} \\
\mathrm{C}>\mathrm{D} \\
\text { n. s. } \\
\text { n. s. } \\
\text { n. s. } \\
\text { C }>\mathrm{D}\end{array}$ \\
\hline $\begin{array}{l}\text { Leaf Surface }\left(\mathrm{cm}^{2} \text { shoot }^{-1}\right) \\
\text { (Cochran } C \text { test } C=0.36 \mathrm{p}=0.22 \text { n. s.) } \\
\text { St } \\
\text { C vs.D } \\
\text { among controls } \\
\text { si(St) } \\
\text { qd(si) } \\
\text { Res } \\
\text { Res (C vs.D) }\end{array}$ & $\begin{array}{c}2 \\
1 \\
1 \\
4 \\
6 \\
12 \\
25\end{array}$ & $\begin{array}{c}26253.13 \\
52270.815 \\
235.445 \\
48.92 \\
57.61 \\
68.86 \\
109.65\end{array}$ & $\begin{array}{c}381.28 * * * \\
776.57 * * \\
3.065 \\
0.71 \\
0.84\end{array}$ & $\begin{array}{c}\mathrm{C} 1=\mathrm{C} 2>\mathrm{D} \\
\mathrm{C}>\mathrm{D} \\
\text { n.s. } \\
\text { n.s. } \\
\text { n.s. }\end{array}$ \\
\hline $\begin{array}{l}\text { Leaf Area Index }\left(\mathrm{m}^{2} \mathrm{~m}^{-2}\right) \\
\text { (Cochran } \mathrm{C} \text { test } \mathrm{C}=0.42 \mathrm{p}=0.59 \text { n. s.) } \\
\text { St } \\
\text { C vs.D } \\
\text { among controls } \\
\text { si(St) } \\
\text { qd(si) } \\
\text { Res } \\
\text { Res (C vs.D) }\end{array}$ & $\begin{array}{c}2 \\
1 \\
1 \\
4 \\
6 \\
12 \\
25\end{array}$ & $\begin{array}{c}171.54 \\
7.668 \\
4.7 \mathrm{E}-3 \\
3.23 \\
1.49 \\
0.97 \\
1.74\end{array}$ & $\begin{array}{c}175.94 * * * \\
303.98 * * \\
0.015 \\
3.32 \\
1.53\end{array}$ & $\begin{array}{c}\mathrm{C} 1=\mathrm{C} 2>\mathrm{D} \\
\mathrm{C}>\mathrm{D} \\
\text { n.s. } \\
\text { n.s. } \\
\text { n.s. }\end{array}$ \\
\hline
\end{tabular}




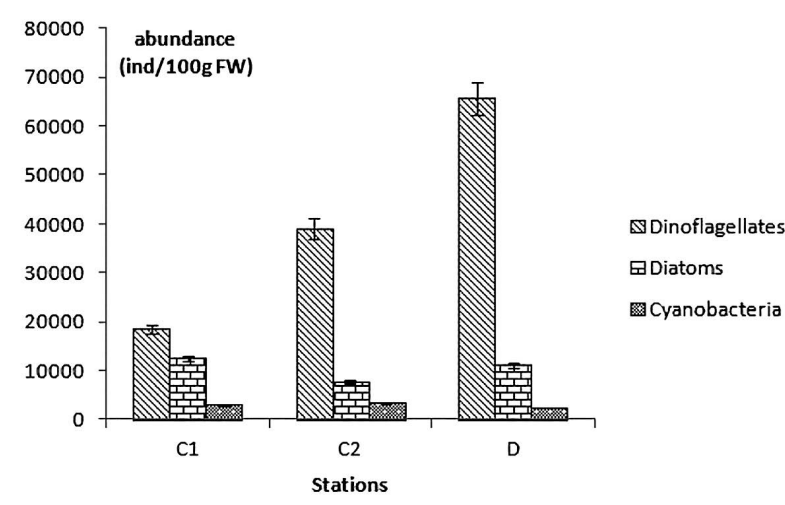

Fig. 3. - Average abundance of microepiphytes on leaves at prospected stations.

tions and the disturbed station. The same results were obtained $(\mathrm{R}=0.615$; $\mathrm{p}=0.01)$ using presence-/absencetransformed data showing that the dissimilarities between stations are due both to species composition and their abundances.

Dinoflagellates, diatoms and cyanobacteria were common epiphytes on leaves (Fig. 3). Abundances of those groups were included in the univariate analyses of variance. Dinoflagellates differed significantly between stations $\left(\mathrm{F}_{(2 ; 12)}=4.63, \mathrm{p}=0.032\right)$ and between the contrast 'disturbed vs. control stations' $\left(\mathrm{F}_{(1 \cdot 25)}=5.47\right.$, $\mathrm{p}=0.028$ ) with high abundance at disturbed station (Tukey test). Significant differences were detected for Prorocentrales and Protoperidiniales when comparing at the level of the stations $\left(\mathrm{F}_{(2 ; 12)}=5.96, \mathrm{p}=0.016\right.$; $\mathrm{F}_{(2 ; 12)}=3.19, \mathrm{p}=0.047$, respectively) and between the contrast 'disturbed vs. control stations' $\left(\mathrm{F}_{(1 ; 25)}=6.97\right.$, $\left.\mathrm{p}=0.014 ; \mathrm{F}_{(1 ; 25)}=15.89, \mathrm{p}<0.001\right)$, with high abundance at disturbed station (Tukey test). When the abundances of toxic dinoflagellates were grouped, significant differences were detected at the level of stations $\left(\mathrm{F}_{(2 ; 12)}=5.57\right.$, $\mathrm{p}=0.019)$ and for the contrast 'disturbed vs. control' $\left(\mathrm{F}_{(1 ; 25)}=3.68, \mathrm{p}=0.043\right)$, with high abundance at the disturbed station. No significant differences for all levels were recorded for diatoms and for cyanobacteria. No significant differences were detected among control stations for all groups (Appendix 2).

SIMPER analyses showed that the average dissimilarity between the control and disturbed group was high $(74.19 \%)$. This procedure also allowed us to determine the species that contribute to this dissimilarity: Prorocentrum concavum, $P$. rathymum, Pinnularia

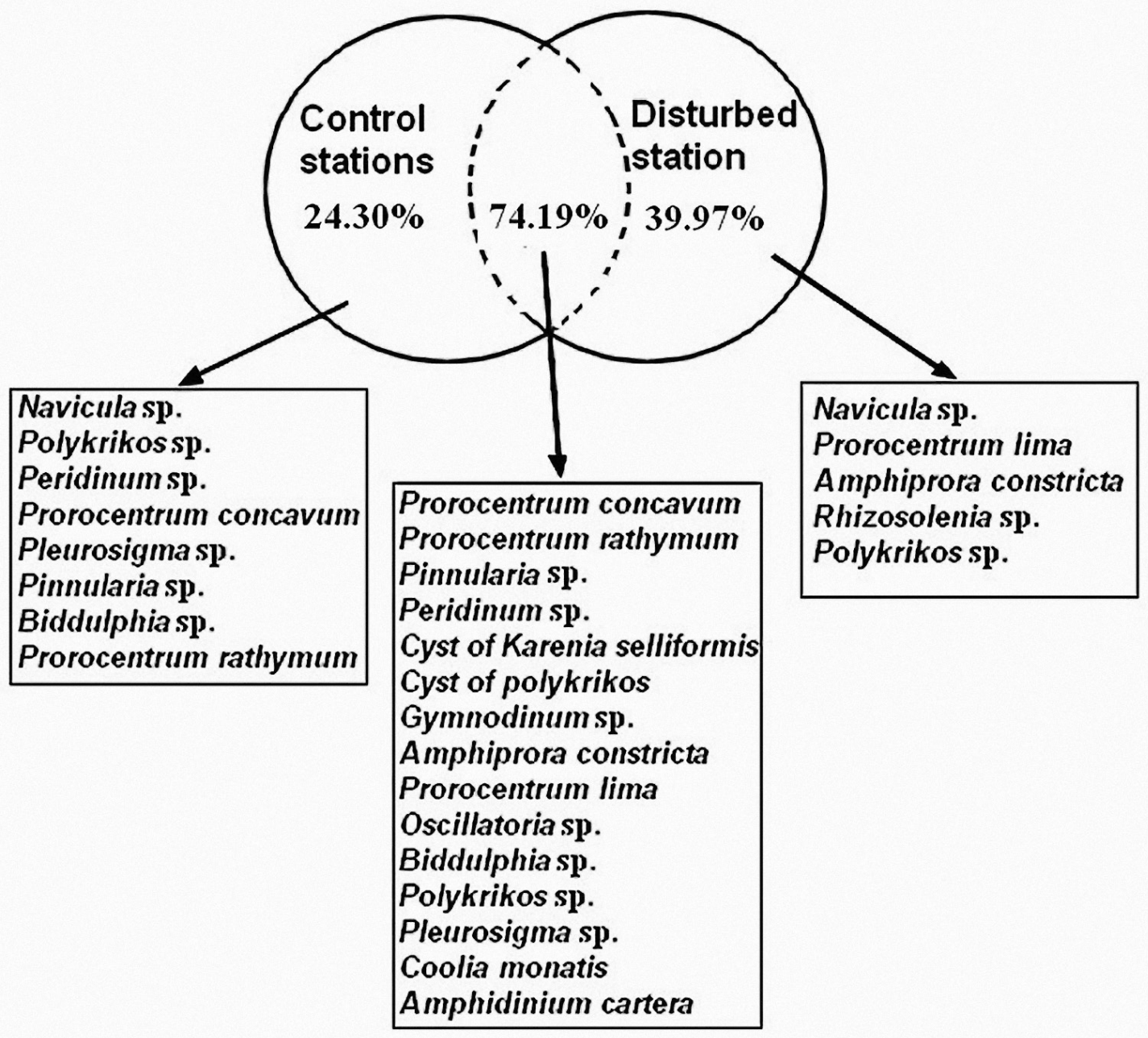

Fig. 4. - Diagram showing the average similarity within each sampling station (continuous line and percentages), the average dissimilarity between control and disturbed station (broken line and percentages), and the distribution of discriminating species following SIMPER results. 


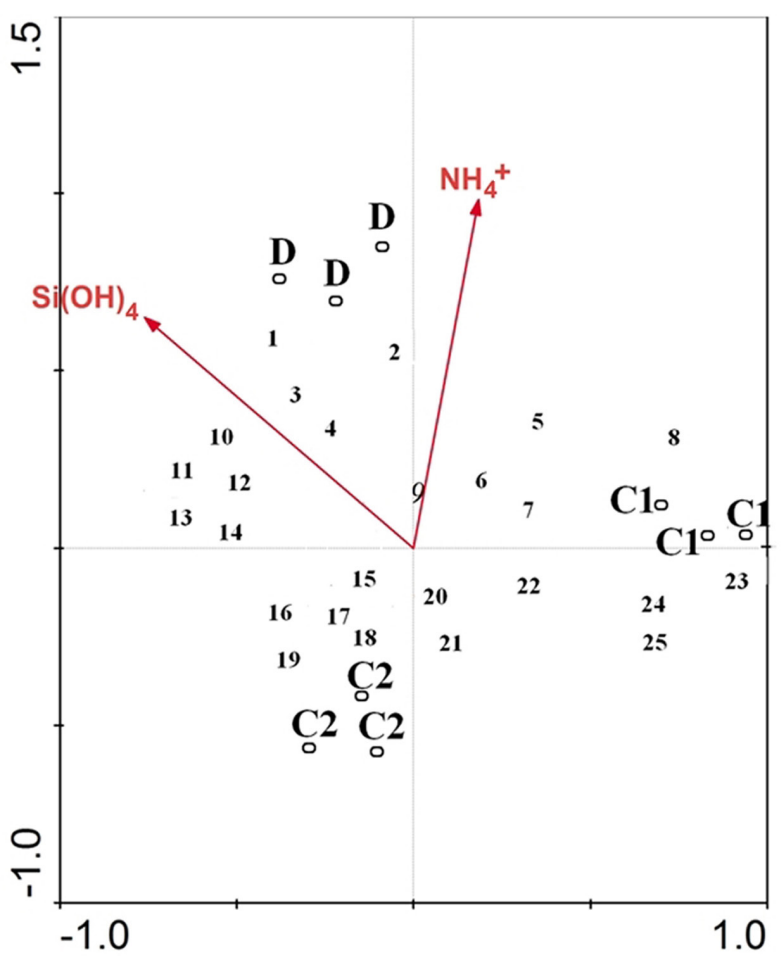

Fig 5. - Diagram of Canonical Correspondence Analysis showing the effects of environmental variables on epiphytic species ordination according to the first and second axes. Number are species: 1 , Protoperidinum sp.; 2, Gyrosigma sp.; 3, Cyst of Polykrikos; 4: Cyst of Karenia selliformis; 5, Licmophora sp.; 6, Prorocentrum lima; 7 , Navicula sp.; 8, Climacosphenia moniligera; 9, Pleurosigma sp.; 10, Prorocentrum concavum; 11, Pinnularia sp.; 12, Biddulphia sp.; 13, Gymnodinium sp.; 14, Prorocentrum rhathymum; 15: Peridinium sp.; 16, Amphidinium carterae; 17, Prorocentrum minimum; 18 , Coolia monotis; 19, Merismopedia sp.; 20, Ostreopsis siamensis; 21, Rhizosolenia sp.; 22, Nitzschia sp.; 23, Amphiprora constricta; 24, Anabaena sp.; 25, Prorocentrum gracile. Species whose coverage and frequency less than $10 \%$ were eliminated.

sp., Peridinium sp., cyst of Karenia selliformis, cyst of Polykrikos, Gymnodinium sp., Amphiprora constricta, Prorocentrum lima, Oscillatoria sp., Biddulphia, Polykrikos sp., Pleurosigma sp., Coolia monatis and Amphidinium cartera (Fig. 4).

CCA analysis indicated that the axis I (eigenvalue $\lambda_{1}=0.324$ ) expressed $74.7 \%$ of the cumulative variance species-environmental variable. Eigenvalues (P-value) calculated with the CCA associated with the analysis in the Monte Carlo test were used to select two statistically significant environmental variables $(\mathrm{p}<0.05)$ that best explain variations $(28.54 \%)$ of species composition: $\mathrm{Si}(\mathrm{OH})_{4}$ and $\mathrm{NH}_{4}{ }^{+}(14.27 \%$ and $11.86 \%$ of total variance, respectively). In the triplot diagram (Fig. 5) disturbed station samples were grouped in the left and are correlated with the axis I, which is defined by the environmental variables $\mathrm{NH}_{4}{ }^{+}$and $\mathrm{Si}(\mathrm{OH})_{4}$ (intra-set correlation 0.639 and 0.439 , respectively). Species placed together with the disturbed station were Protoperidinium sp. and Gymnodinium sp. The orthogonal projection of these species on environmental variables showed that they have important preferences for $\mathrm{NH}_{4}^{+}$ and $\mathrm{Si}(\mathrm{OH})_{4}$. Most other species have a midway position between the three stations, which suggests that they have quite similar frequencies and abundances among the three stations.

\section{DISCUSSION}

Our study shows two main results: (1) A decline in meadow vitality at the disturbed station compared with control sites, and (2) The abundance and composition of epiphytic microalgae changes at the disturbed station through an increase of dinoflagellate abundance.

Our data showed a moderate nutrient enrichment at the disturbed station that did not reach an eutrophication stage because the concentrations were not high enough, but the transparency was very low due to suspended solids discharged from the outfall.

The multivariate analysis illustrates a decrease in seagrass leaf biometric parameters (shoot density, leaf length, leaf surface and leaf area index) at disturbed vs. control stations, thus indicating the inability of disturbed meadows to withstand increasing urban interferences. The number of leaves per shoot was not different between stations, a finding which is consistent with previous studies (Capiomont et al. 2000, Mabrouk et al. 2013). A decline in shoot density, leaf area index, leaf surface and leaf length at disturbed stations compared with control sites has been found by several authors (Leriche et al. 2004, Ben Brahim et al. 2010). These results cannot be assigned only to nutrient enrichment; several factors may also explain this decline: first, the decrease in water transparency at the disturbed station (Table 1) involves the reduction of light intensity necessary for photosynthesis. Second, the decrease in salinity following the discharge of sewage could affect plant biometric parameters (Ben Alaya 1972). In addition, pollutants affect the vitality and physiology of Posidonia (Augier and Maudinas 1979, Pergent-Martini and Pergent 2000). The National Sanitation Utility in Tunisia (ONAS, 2008) claimed that discharge into the sea in northern Tunisia caused high turbidity and sediment pollution (high content of total organic carbon, fairly high levels of nitrates and metals such as $\mathrm{Fe}, \mathrm{Mn}, \mathrm{Zn}, \mathrm{Pb}, \mathrm{Ni}, \mathrm{Co}, \mathrm{Pb}$ and $\mathrm{Cd}$ ).

The diversity of epiphytic microorganisms on the leaves of Posidonia oceanica was high along the Mahdia coast. confirming previous findings indicating that vegetated ecosystems are ideal habitats for benthic diatoms and other epiphytes (Cummins et al. 2004). This is because seagrass leaves and algal thalli may represent a surface area one order of magnitude greater for the colonization and growth of diatoms (Zieman et al. 1989). Our results show that the abundance and composition of microepiphytes changes at the disturbed station, with an increase in abundance of dinoflagellates, especially from the orders Prorocentrales and Protoperidiniales. These results are similar to those found by Ben Brahim et al. (2013) in southern Tunisia (Gulf of Gabes). Some fertilization experiments have shown shifts in relative dominance among algal species, with a shift towards cyanobacteria (Armitage et al. 2006) and diatoms (Frankovich et al. 2009) under nutrient enrichment.

There is an evident difference of epiphytic composition between control and disturbed stations, but those changes can be attributed to the moderate nutrient enrichment or to the low transparency detected 
at sites around the outfall. It is known that nutrient enrichment stimulates the growth of epiphytic algae (Moore and Wetzel 2000) and causes changes in their species composition (Wear et al. 1999). However, each microalgal group displays a unique spatial pattern in response to $\mathrm{N}$ and $\mathrm{P}$ enrichment (Armitage et al. 2006). Our data show that there is an increase in dinoflagellates at the disturbed station compared with control sites but no significant differences are found for diatoms and cyanobacteria. Armitage et al. (2006) also found that diatoms did not response to nutrient enrichment. It seems that dinoflagellates tolerate better those environmental variations. Baker et al. (2007) have suggested that some taxa of this latter group may have several significant ecophysiological differences when compared with diatoms, dealing with variations in their chemical and physical environment (e.g. nutrients, light and temperature), such as a lower affinity for nutrients, considerable nutritional diversity, and motility. In addition, Prézelin and Haxo (1976) have shown that in dinoflagellates grown under low light intensity, a greater proportion of the chlorophyll a is localized in PCP complexes (peridinin chlorophyll $a$ proteins), providing an increased light-gathering capacity. Light is a factor that influences the composition of epiphytes at the polluted station. Indeed, turbidity at this station reduces the light intensity that reaches the meadow and hence the dominance of some tolerant species such as members of the order Prorocentrales. These species have an optimum light intensity lower than $10 \%$ of sunlight (Morton et al. 1992).

Phytoplankton species respond in different ways to nutrient enrichment, probably based on their life cycle characteristics, such as growth rate and their absorptive capacity (Philippart et al. 2000). According to Lepoint et al. (2007), it is difficult to predict which group would be favored by the moderate intake of nutrients. Lin et al. (1996) found that nutrient enrichment $\left(\mathrm{NO}_{3}{ }^{-}, \mathrm{NH}_{4}{ }^{+}\right.$, $\mathrm{PO}_{4}^{-}$, either alone or in combination) did not result in an increase in the abundance of epiphytes on Zostera marina. These communities respond in complex ways to the addition of nutrients. The seasonal influence on the response of algae epiphytic nutrient enrichment seems important (Neckles 1993). For example, the increased epiphytic load on Z. marina because of the high nitrogen loading occurred only in summer (Hauxwell et al. 2003). Therefore, the dominance of a group is either transient or steady but highly seasonal, coinciding with seasonal events of nutrient inputs (Ierodiaconou and Laurenson 2002). Harrison et al. (1991) found that high organic matter and nutrient enrichment caused the increase in centric diatoms (such as Thalassionema, Rhizosolenia, Striatella, Skletonema). Shen (2001) found that the limitation of silicon did not cause a change in species abundance of diatoms but had an effect on cell size, which was smaller than those at control stations.

It seems that the response of the epiphytic community depends on the nature and degree of nutrient enrichment. For example, Silicon ( $\mathrm{Si}$ ) played the most important role in the growth and development of diatoms, while dinoflagellates were mostly controlled by phosphorus (P) availability (Chikhaoui et al. 2008). When phosphorus loading increased, a shift from diatoms to dinoflagellates was observed (Hodgkiss 2001). In the same vein, in Tunisian aquaculture lagoons, blooms of toxic dinoflagellates have been shown to develop when the N:P ratio drops in autumn (Romdhane et al. 1998). Increases in the N:Si ratio were proportional to the increase in flagellates (Smayda et al. 2004) and the decrease in diatoms abundance (Anderson et al. 2002).

The epiphyte-grazer interaction also plays an important role in controlling the abundance and diversity of epiphytes. Indeed, the epiphytes of marine macrophytes are a food source for a range of grazers and predators and, in turn, they influence the diversity and abundance of epiphytes by removing the substrate and biomass of the host plant (Jernakoff et al. 1996, Borowitzka et al. 2006). Grazers can be highly selective (Cattaneo 1983), making the potential effects of nutrient enrichment undetectable (Neckles et al. 1994, Heck and Valentine 2007), and they may thus have a strong effect on the spatial pattern of the periphytic community (Sarnelle et al. 1993). Some grazers (scrapers) feed preferentially on tightly attached diatoms (Mazzella and Russo 1989), whereas others (surfers) favour stalked and filamentous diatoms (Tall et al. 2006). Neckles et al. (1994) showed that numbers of diatoms decreased in the presence of grazers and showed little response to nutrient enrichment. This may be a possible explanation for the absence of variation of diatoms at our studied sites.

Another hypothesis that may explain changes in epiphytic microalgae at the polluted station is that the abundance of epiphytes is correlated with leaf phenological parameters of the host plant (RELATE procedure). The decrease in biometric parameters of Posidonia at the disturbed station (Fig. 2, Table 2) induces changes in the abundance of microepiphytes. This result has been also found by previous studies (Johnson et al. 2005, Mabrouk et al. 2011)

Our results also show an increase at the disturbed station in the abundance of potentially toxic dinoflagellates such as Alexandrium minitum, Amphidinium carterae, Karenia selliformis, Coolia monatis, Karlodinium veneficum, Ostreopsis siamensis, Prorocentrum concavum, $P$. minimum, $P$. rathymum and $P$. lima. Some of them are potential toxin producers (Nakajima et al. 1981). Epiphytic Prorocentrum species are mainly associated with okadaic acid and the production of analogues (Faust 1991, Nascimento et al. 2005). These findings support those of Romdhane et al. (1998) and Armi et al. (2010) in Tunisia and those of Aligizaki and Nikolaidis (2006), Mangialajo et al. (2008) and Totti et al. (2010) in the northern Mediterranean Sea. All those surveys demonstrated that the increase in dinoflagellates, including the toxic species, is related to the increase in nutrient enrichments which is species-specific (Anderson et al. 2002). These results are particularly useful in this area, with the recent establishment of several fish farms, since epiphytic dinoflagellates are easily resuspended in the water column (Mabrouk et al. 2012). Moreover, Marr et al. 
(1992) concluded that the underestimation of toxic dinoflagellates associated with a toxic event might be due, in part, to the lack of sampling of the benthic and epiphytic communities.

Finally, it is necessary to improve a management programme to protect $P$. oceanica and its associated epiphytes in Ben Ghayadha, respecting the guideline of UNEP/WHO (1996), which recommended that discharges in the direct vicinity of Posidonia beds should be avoided whenever possible.

The present study underlines the use of epiphytic microalgae assemblages in seagrass ecosystems as general indicators of anthropogenic disturbance to seagrass meadows. It was clear that the effect of nutrient loading and turbidity could be depicted in the community structure and diversities of seagrass-associated epiphytes (Balata et al. 2008, Ben Brahim et al. 2010, Mabrouk et al. 2013, this study). During the period of study (August), nutrient enrichment (mainly $\mathrm{Si}(\mathrm{OH})_{4}$ and $\mathrm{NH}_{4}^{+}$) and turbidity were associated with an increase in abundance of dinoflagellates, especially Protoperidiniales and Prorocentrales. The results of this survey can be used to compare with other regions in the Mediterranean subjected to same conditions where we can observe the deterioration in vitality of Posidonia oceanica meadow and increases in dinoflagellates.

\section{ACKNOWLEDGEMENTS}

This study was supported by the research project EBHAR 'État du Benthos et des Habitats Remarquables' of the National Institute of Sciences and Technology of the Sea (INSTM). We also thank editors and reviewers for their comments, which improved the quality of the manuscript.

\section{REFERENCES}

Aligizaki K., Nikolaidis G. 2006. The presence of the potentially toxic genera Ostreopsis and Coolia (Dinophyceae) in the North Aegean Sea, Greece. Harmful Algae 5: 717-730. http://dx.doi.org/10.1016/j.hal.2006.02.005

Anderson D.M., Glibert P.M., Burkholder J.M. 2002. Harmful Algal Blooms and Eutrophication: Nutrient Sources, Composition, and Consequences. Estuaries 25: 704-726. http://dx.doi.org/10.1007/BF02804901

Armi Z., Turki S., Trabelsi E., BenMaiz N. 2010. First recorded proliferation of Coolia monotis (Meunier, 1919) in the North Lake of Tunis (Tunisia) correlation with environmental factors. Environ. Monit. Assess. 164: 423-433. http://dx.doi.org/10.1007/s10661-009-0903-z

Armitage A.R., Frankovich T.A., Fourqurean J.W. 2006. Variable responses within epiphytic and benthic microalgal communities to nutrient enrichment. Hydrobiologia 569: 423-435. http://dx.doi.org/10.1007/s10750-006-0146-8

Augier H., Maudinas B. 1979. Influence of the pollution on the photosynthetic pigments of the marine phanerogam Posidonia oceanica collected from different polluted areas of the Region of Marseille (Mediterranean sea, France). Oecolog. Plantar. 14(2): 169-176.

Baker J.W., Groyer J.P. Brooks B.W., Ure-a-Boeck F, Roelke D.L., Errera R.M., Kiesling R. 2007. Growth and toxicity of Prymnesium parvum (Haptophyta) as a function of salinity, light and temperature. J. Phycol. 43: 219-222. http://dx.doi.org/10.1111/j.1529-8817.2007.00323.x

Balata D., Bertocci I., Piazzi L., Nesti N. 2008 Comparison between epiphyte assemblages of leaves and rhizomes of the seagrass Posidonia oceanica subjected to different levels of anthropogenic eutrophication. Estuar. Coast Shelf. Sci. 79: 533-540. http://dx.doi.org/10.1016/j.ecss.2008.05.009

Ben Alaya H. 1972. Répartition et conditions d'installation de Posidonia oceanica Delile et Cymodocea nodosa Ascherson dans le golfe de Tunis. Bull. Inst. Nat. Sc. et Tech. d'Océanographie et de Pèche de Salammbo 2: 331-416.

Ben Brahim M., Hamza A., Hannachi I., Rebai A., Jarboui O., Bouain A., Aleya L. (2010). Variability in the structure of epiphytic assemblages of Posidonia oceanica in relation to human interferences in the Gulf of Gabes, Tunisia. Mar. Environ. Res. 70: 411-421. http://dx.doi.org/10.1016/j.marenvres.2010.08.005

Ben Brahim M, Hamza A., Ben Ismail S., Mabrouk L., Bouain A., Aleya L. 2013. What factors drive seasonal variation of phytoplankton, protozoans and metazoans on leaves of Posidonia oceanica and in the water column along the coast of the Kerkennah Islands, Tunisia? Mar. Pollut. Bull. 71: 286-298. http://dx.doi.org/10.1016/j.marpolbul.2013.01.024

Borowitzka M.A., Lavery P., Keulen M. (2006). Epiphytes of Seagrasses. In: Larkum A.W.D., Orth R.J., Duarte C.M. (eds), Seagrasses: Biology, Ecology and Conservation. Springer, The Netherlands: 441-461. http://dx.doi.org/10.1007/1-4020-2983-7_19

Cambridge M.L., Chiffings A.W., Brittan C., Moore L., McComb A.J. 1986. The loss of seagrass in Cockburn Sound, Western Australia. Possible causes of seagrass decline. Aquat. Bot. 24: 269-285. http://dx.doi.org/10.1016/0304-3770(86)90062-8

Cancemi G., De Falco G., Pergent G. 2003. Effects of organic matter input from a fish farming facility on Posidonia oceanica meadow. Estuar. Coast. Shelf Sci. 56: 961-968. http://dx.doi.org/10.1016/S0272-7714(02)00295-0

Capiomont A., Piazzi L., Pergent G. 2000. Seasonal variations of total mercury in foliar tissues of Posidonia oceanica. J. Mar. Biol. Assoc. U. K. 80: 1119-1123. http://dx.doi.org/10.1017/S0025315400003192

Cattaneo A. 1983. Grazing on epiphytes. Limnol. Oceanogr. 28: 124-132. http://dx.doi.org/10.4319/lo.1983.28.1.0124

Chikhaoui M.A., Hlaili A.S., Mabrouk H.H. 2008. Seasonal phytoplankton responses to N:Si:P enrichment ratio in the Bizerte Lagoon (southwestern Mediterranean). C. R. Biol. 331(5): 389408. http://dx.doi.org/10.1016/j.crvi.2008.03.005

Chung M.H., Lee K.S. 2008. Species composition of the epiphytic diatoms on the leaf tissues of three Zostera species distributed on the southern coast of Korea. Algae 23: 75-81. http://dx.doi.org/10.4490/ALGAE.2008.23.1.075

Clarke K.R. 1993. Nonparametric multivariate analyses of changes in community structure. Aust. J. Ecol. 18: 117-143. http://dx.doi.org/10.1111/j.1442-9993.1993.tb00438.x

Clarke K.R., Warwick R.M. 2001. Change in marine communities: an approach to statistical analysis and interpretation. PRIMERE Ltd. Plymouth, UK, 172 pp.

Cummins S.P., Roberts D.E., Ajani P., Underwood A.J. 2004. Comparisons of assemblages of phytoplankton between open water and seagrass habitats in a shallow coastal lagoon. Mar. Freshwater. Res. 55: 447-456. http://dx.doi.org/10.1071/MF04017

Faust M.A. 1991. Morphology of ciguatera-causing Prorocentrum lima (Pyrrhophyta) from widely differing sites. J. Phycol. 27: 642-648. http://dx.doi.org/10.1111/j.0022-3646.1991.00642.x

Frankovich T.A., Zieman J.C. 1994. Total epiphyte and epiphytic carbonate production on Thalassia testudinum across Florida Bay. Bull. Mar. Sci. 54: 679-695.

Frankovich T.A., Armitage A.R., Wachnicka A., Gaiser E.E., Fourqurean J.W. 2009. Nutrient effects on seagrass epiphyte community structure in Florida Bay. J. Phycol. 45: 1010-1020. http://dx.doi.org/10.1111/j.1529-8817.2009.00745.x

Gambi M.C., Lorenti M., Russo G.F., Scipione M.B., Zupo V. 1992. Depth and seasonal distribution of some groups of the vagile fauna of the Posidonia oceanica leaf stratum- structural and trophic analyses. Mar. Ecol. 13: 17-39. http://dx doi.org/10.1111/j.1439-0485.1992.tb00337.x

Giraud G. 1979. Sur une méthode de mesure et de comptage des structures foliaires de Posidonia oceanica (Linnaeus) Delile. Bull. Mus. Hist. nat. Marseille 39: 33-39.

Grasshoff K., Ehrhardt M., Kremling K. 1983. Methods of Seawater Analysis. Verlag Chemie GmbH, Weinheim, Germany, 419 pp.

Green E.P., Short F.T. 2003. World Atlas of Seagrasses. University of California Press, Berkeley, USA, 286 pp.

Harrison P.J., Clifored P.J., Cochlan W.P., Yin K., St. John M.A., Thompson P.A., Sibbald M.J., Albright L.J. 1991. Nutriment and plankton dynamics in the Frazer River Plume, Strait of Georgia, British Columbia. Mar. Ecol. Prog. Ser. 70: 291-304. http://dx.doi.org/10.3354/meps070291

Hauxwell J., Cebrian J., Valiela I. 2003. Eelgrass Zostera marina 
loss in temperate estuaries: Relationship to land-derived nitrogen loads and effect of light limitation imposed by algae. Mar. Ecol. Prog. Ser. 247: 59-73. http://dx.doi.org/10.3354/meps 247059

Heck Jr. K.L., Valentine J.F. 2007. The primacy of top-down effects in shallow benthic ecosystems. Estuar. Coast 30: 371-381. http://dx.doi.org/10.1007/BF02819384

Hodgkiss I.J. 2001. The N:P ratio revisited. In: Ho, K.C., Wang, Z.D. (eds), Prevention and Management of Harmful Algal Blooms in the South China Sea. School of Science and Technology, the Open University of Hong Kong: 344-355.

Ierodiaconou D. A., Laurenson L.J.B. 2002. Estimates of Heterozostera tasmanica, Zostera muelleri and Ruppia megacarpa distribution and biomass in the Hopkins Estuary, Western Victoria, by GIS. Aust. J. Bot. 50: 215-228. http://dx.doi.org/10.1071/BT00093

Jernakoff P., Nielsen J. 1997. The relative importance of amphipod and gastropod grazers in Posidonia sinuosa meadows. Aquat. Bot. 56: 183-202 http://dx.doi.org/10.1016/S0304-3770(96)01112-6

Jernakoff P., Brearley B., Nielsen J. 1996. Factors affecting grazerepiphyte interactions in temperate seagrass meadows. Oceanogr. Mar. Biol. Ann. Rev. 34: 109-162.

Johnson M.P., Edwards M., Bunker F., Magg C.A. 2005. Algal epiphytes of Zostera marina: Variation in assemblage structure from individual leaves to regional scale. Aquat. Bot. 82: 12-26. http://dx.doi.org/10.1016/j.aquabot.2005.02.003

Kendrick G.A., Lavery P.S. 2001. Assessing biomass, assemblage structure and productivity of algal epiphytes on seagrasses. In: Short F.T., Coles R.G. (eds), Glogal Seagrass Research Methods. Elsevier, Amesterdam. pp. 199-222.

Lepoint G., Jacquemart J., Bouquegneau J.M., Demoulin V., Gobert S. 2007. Field measurements of inorganic nitrogen uptake by epiflora components of the seagrass Posidonia oceanica (Monocotyledons, Posidoniaceae). J. Phycol. 43: 208-218. http://dx.doi.org/10.1111/j.1529-8817.2007.00322.x

Leriche A., Boudouresque C.F., Bernard G., Bonhomme P., Denis J., 2004. A one-century suite of seagrass bed maps: can we trust ancient maps? Estuar. Coast. Shelf Sci. 59: 353-362. http://dx.doi.org/10.1016/j.ecss.2003.09.007

Lin H.J., Nixon S.W., Taylor D.I., Granger S.L., Buckley B.A. 1996. Responses of epiphytes on eelgrass, Zostera marina L. to separate and combined nitrogen and phosphorus enrichment. Aquat. Bot. 52: 243-258 http://dx.doi.org/10.1016/0304-3770(95)00503-X

Mabrouk L., Hamza A., Sahraoui H., Bradai M.N. 2009. Caractéristique et phénologie de l'herbier de Posidonia oceanica (L.) Delile sur les côtes de Mahdia (région est de la Tunisie). Bull. Inst. Nat. Sc. et Tech. d'Océanographie et de Pèche de Salammbo 36: 139-148.

Mabrouk L., Hamza A., Ben Brahim M., Bradai M.N. 2011. Seasonal and bathymetric variations of epiphytic microorganisms on Posidonia oceanica (L.) Delile leaves in Mahdia (Tunisia). Mar. Ecol. 32: 148-161 http://dx.doi.org/10.1111/j.1439-0485.2011.00432.x

Mabrouk L., Hamza A., Mahfoudi M., Bradai M.N. 2012. Spatial and temporal variations of epiphytic Ostreopsis siamensis on Posidonia oceanica (L.) Delile leaves in Mahdia (Tunisia). Cah. Biol. Mar. 53: 419-427.

Mabrouk L. Hamza A., Ben Brahim M., Bradai MN. 2013. Variability in the structure of epiphyte assemblages on leaves and rhizomes of Posidonia oceanica in relation to human disturbances in a seagrass meadow off Tunisia. Aquat. Bot. 108: 3340. http://dx.doi.org/10.1016/j.aquabot.2013.03.002

Mangialajo L., Bertolotto R., Cattaneo Vietti R., Chiantore M., Grillo C., Lemee R., Melchiorre C., Moretto P., Povero P., Ruggieri N. 2008. The toxic benthic dinoflagellate Ostreopsis ovata: Quantification of proliferation along the coastline of Genoa, Italy. Mar. Pollut. Bull. 56: 1209-1214 http://dx.doi.org/10.1016/j.marpolbul.2008.02.028

Marbà N., Santiago R., Diaz-Almela E., Alvarez E., Duarte C.M. 2006. Seagrass (Posidonia oceanica) vertical growth as an early indicator of fish farm-derived stress. Estuar. Coast Shelf. Sci. 67: 475-483. http://dx.doi.org/10.1016/j.ecss.2005.11.034

Marr J.C., Jackson A.E., McLachlan J.L. 1992. Occurrence of Prorocentrum lima, a DSP toxin-producing species from the Atlantic coast of Canada. J. Appl. Phycol., 4: 17-24. http://dx.doi.org/10.1007/BF00003956

Mazzella L., Russo G.F., 1989. Grazing effect of two Gibbula species (Mollusca, Archaeogastropoda) on the epiphytic com- munity of Posidonia oceanica leaves. Aquat. Bot. 35: 357-373. http//dx doi org/10.1016/0304-3770(89)90007-7

Mazzella L., Scipione M.B., Buia M.C. 1989. Spatio-temporal distribution of algal and animal communities in a Posidonia oceanica (L.) Delile meadow. Mar. Ecol. 10: 107-131. http://dx.doi.org/10.1111/j.1439-0485.1989.tb00069.x

Montefalcone M. 2009. Ecosystem health assessment using the Mediterranean seagrass Posidonia oceanica: a review. Ecol. Indic. 9: 595-604. http://dx.doi.org/10.1016/j.ecolind.2008.09.013

Montefalcone M., Chiantore M., Lanzone A., Morri C., Bianchi C.N., Albertelli G. 2008. BACI design reveals the decline of the seagrass Posidonia oceanica induced by anchoring. Mar. Pollut. Bull. 56: 1637-1645. http://dx.doi.org/10.1016/j.marpolbul.2008.05.013

Moore K.A., Wetzel R.L. 2000. Seasonal variations in eelgrass (Zostera marina L.) responses to nutrient enrichment and reduced light availability in experimental ecosystems. J. Exp. Mar. Biol. Ecol. 244: 1-28. http://dx doi.org/10.1016/S0022-0981(99)00135-5

Morton S.L., Norris D.R., Bomber J.W. 1992. Effect of temperature, salinity and light intensity on the growth and seasonality of toxic dinoflagellates associated with ciguatera. J. Exp. Mar. Biol. Ecol. 157: 79-90. http://dx.doi.org/10.1016/0022-0981(92)90076-M

Nakajima I., Oshima Y., Yasumoto T. 1981. Toxicity of benthic dinoflagellates in Okinawa. B. JPN. Soc. Sci. Fish. 47: 10291033. http://dx.doi.org/10.2331/suisan.47.1029

Nascimento S.M., Purdie D.A., Morris S. 2005. Morphology, toxin composition and pigment content of Prorocentrum lima strains isolated from a coastal lagoon in southern UK. Toxicon 45: 633-649. http://dx.doi.org/10.1016/j.toxicon.2004.12.023

Neckles H. A. 1993. The role of epiphytes in seagrass production and survival: Microcosm studies and simulation modelling. In: Morris L.J., Tomasko D.A. (eds), Proceedings and Conclusions of Workshops on: Submerged Aquatic Vegetation and Photosynthetically Active Radiation. Special Publication St Johns River Water Management District, Palatka, Florida, pp. 91-105.

Neckles H.A., Koepfler E.T., Haas L.W., Wetzel R.L., Orth R.J., 1994. Dynamics of epiphytic photoautotrophs and heterotrophs in Zostera marina (eelgrass) microcosms: responses to nutrient enrichment and grazing. Estuaries 17: 597-605. http://dx.doi.org/10.2307/1352407

Nesti U., Piazzi L., Balata D. 2009. Variability in the structure of epiphytic assemblages of the Mediterranean seagrass Posidonia oceanica in relation to depth. Mar. Ecol. 30 : 276-287. http://dx.doi.org/10.1111/j.1439-0485.2008.00275.x

ONAS. 2008. Etude de pré-investissement sur la dépollution du golfe de Tunis-Titre II: Caractérisation du golfe de Tunis Synthèse. Synthèse générale sur l'état du golfe de Tunis. 12 pp. http://www.environnement.gov.tn/fileadmin/medias/pdfs/ prev risq/prev_risq synthese generale.pdf

Orth R.J., Carruthers T.J.B., Dennison W.C., Duarte C.M., Fourqurean J.W., Heck Jr K.L., Hughes A.R., Kendrick G.A., Kenworthy W.J., Olyarnik S., Short F.T., Waycott M., Williams S.L. 2006. A global crisis for seagrass ecosystems. Bioscience 56: $987-$ 996. http://dx.doi.org/10.1641/0006-3568(2006)56[987:AGCF $\mathrm{SE}] 2.0 \mathrm{CO} \cdot 2$

Pergent G., Pergent-Martini C., Boudouresque C.F. 1995. Utilisation de l'herbier à Posidonia oceanica comme indicateur biologique de la qualité du milieu littoral en Méditerranée: état des connaissances. Mésogée 54: 3-29.

Pergent-Martini C., 1994. Impact d'un rejet d'eaux usées urbaines sur l'herbier à Posidonia oceanica, avant et après la mise en service d'une station d'épuration. $\mathrm{PhD}$ thesis, University of Corsica, Corte, France, 191 pp.

Pergent-Martini C., Pergent G., 2000. Marine phanerogams as a tool in the evaluation of marine trace-metal contamination: an example from the Mediterranean. Int. J. Environ. Pollut. 13: 1-6. http://dx.doi.org/10.1504/IJEP.2000.002313

Philippart C.J.M., Cadee G.C., Raaphorst W.V., Riegman R. 2000. Long-term phytoplankton-nutrient interactions in a shallow coastal sea: algal community structure, nutrient budgets, and denitrification potential. Limnol. Oceanogr. 45: 131-144. http://dx.doi.org/10.4319//o.2000.45.1.0131

Piazzi L., Balata D., Cinelli F., Benedetti-Cecchi L. 2004. Patterns of spatial variability in epiphytes of Posidonia oceanica. Differences between a disturbed and two reference locations. Aquat. Bot. 79: 345-356. http://dx.doi.org/10.1016/j.aquabot.2004.05.006

Prézelin B.B., Haxo F.T. 1976. Purification and characterization of peridinin- chlorophyll a-proteins from the marine dinoflagel- 
lates Gleodinium sp. and Gonyaulax polyedra. Planta (Berl). 128: 133-141. http://dx.doi.org/10.1007/BF00390314

Romdhane M.S., Eilertsen H.C., Yahia O.K.D., Yahia M.N.D., 1998. Toxic dinoflagellate blooms in Tunisian lagoons: causes and consequences for aquaculture. In: Reguera B., Blanco J., Fernandez M.L., Wyatt T. (eds), Harmful Algae. Xunta de Galicia and Intergovernmental Oceanographic Commission of UNESCO, Vigo, pp. 80-83.

Ruiz J.M., Pérez M., Romero J., Tomas F. 2009. The importance of herbivory in the decline of a seagrass (Posidonia oceanica) meadow near a fish farm: an experimental approach. Bot. Mar. 52: 449-458. http://dx.doi.org/10.1515/BOT.2009.053

Sarnelle O., Kratz K.W., Cooper S.D. 1993. Effects of an invertebrate grazer on the spatial arrangement of a benthic microhabitat. Oecologia 96: 208-218. http://dx.doi.org/10.1007/BF00317734

Shen Z.L. 2001. Historical changes in nutrient structure and its influences on phytoplantkon composition in Jiaozhou Bay. Estuar. Coast. Shelf Sci. 52: 211-224. http://dx doi.org/10.1006/ecss.2000.0736

Sirota L., Hovel K.A. 2006. Eelgrass (Zostera marina) structural complexity: relative effects of shoot length, shoot density, and surface area on epifaunal community composition in San Diego Bay, California, USA. Mar. Ecol. Prog. Ser. 326: 115-131. http://dx.doi.org/10.3354/meps326115

Smayda T.J., Borkman D.G., Beaugrand G., Belgrano A.G. 2004 Ecological effects of climate variation in the North Atlantic: phytoplankton. In: Stenseth N.C., Ottersen G., Hurrell J., Belgrano A. (eds), Ecological Effects of Climate Variations in the North Atlantic. Oxford Univ. Press, pp. 49-54.

Somerfield P.J., Clarke K.R., Olsgard F. 2002. A comparison of the power of categorical and correlational tests applied to community ecology data from gradient studies. J. Anim. Ecol. 71: 581-593. http://dx.doi.org/10.1046/j.1365-2656.2002.00624.x

Sournia, A. (ed.). 1978. Phytoplankton manual. Monogr. oceanogr. Methodol. Unesco 6: xvi-337 pp

Tall L., Cattaneo A., Cloutier L., Dray S., Legendre P. 2006. Re- source partitioning in a grazer guild feeding on a multilayer diatom mat. J. N. Am. Benthol. Soc. 25: 800-810. http://dx.doi.org/10.1899/0887-3593(2006)025[0800:RPIAGG 12.0.CO;2

ter Braak C.J.F., Verdonschot P.F.M. 1995, Canonical correspondence analysis and related multivariate methods in aquatic ecology. Aquat. Sci. 57: 255-289. http://dx.doi.org/10.1007/BF00877430

Totti C., Accoroni S., Cerino F., Cucchiari E., Romagnoli T. 2010. Ostreopsis ovata bloom along the Conero Riviera (northern Adriatic Sea): Relationships with environmental conditions and substrata. Harmful Algae 9: 233-239. http://dx.doi.org/10.1016/j.hal.2009.10.006

Turki S. 2005. Distribution of toxic dinoflagellates along the leaves of seagrass Posidonia oceanica and Cymodocea nodosa from the Gulf of Tunis. Cah. Biol. Mar. 46: 29-34.

Underwood A.J. 1992. Beyond BACI: the detection of environmental impacts on populations in the real, but variable, world. J. Exp. Mar. Biol. Ecol. 161: 145-178. http://dx.doi.org/10.1016/0022-0981(92)90094-Q

UNEP/WHO 1996. Guidelines for submarine outfall structures for Mediterranean small and medium-sized coastal communities. MAP Technical Reports Series, 112. UNEP, Athens.

Utermöhl H. 1958. Zur vervollkommung der quantitativen Phytomicroorganisms-Methodik. Mitteilungen. Verhandlungen der Internationalen Vereinigung für Theoretische und Angewandte Limnologie 9: 1-38.

Wear D.J., Sullivan M.J., Moore A.D., Millie D.F. 1999. Effects of water-column enrichment on the production dynamics of three seagrass species and their epiphytic algae. Mar. Ecol. Prog. Ser. 179: 201-213. http://dx.doi.org/10.3354/meps179201

Zar J.H. 1999. Biostatistical analysis (Fourth ed.). Upper Saddle River, N.J. Prentice Hall, New Jersey, 663 pp.

Zieman J.C. 1989. Distribution, abundance and productivity of seagrasses and macroalgae in Florida Bay. Bull. Mar. Sci. 44: 292-311. 
Appendix 1. - Species list of microepiphytes identified on the leaves of P. oceanica at all prospected stations.

\begin{tabular}{|c|c|c|c|}
\hline Groups & Species & Control stations & Disturbed station \\
\hline \multirow[t]{25}{*}{ Diatoms } & Achnanthes sp. & + & - \\
\hline & Amphiprora constricta (Ehrenberg 1843) & + & - \\
\hline & Amphora sp. & + & + \\
\hline & Bacillaria sp. & + & - \\
\hline & Biddulphia sp. & + & + \\
\hline & Chamaesiphon sp. & + & - \\
\hline & Chaetoceros sp. & + & + \\
\hline & Climacosphenia moniligera (Ehrenberg 1843) & + & - \\
\hline & Coscinodiscus sp. & + & - \\
\hline & Grammatophora sp. & + & + \\
\hline & Gyrosigma sp. & + & + \\
\hline & Leptocylindrus sp. & + & - \\
\hline & Licmophora sp. & + & + \\
\hline & Melosira sp. & + & - \\
\hline & Navicula sp. & + & + \\
\hline & Nitzschia fontifuga (Cholnoky 1962) & + & + \\
\hline & Nitzschia sp. & + & + \\
\hline & Pinnularia sp. & + & + \\
\hline & Plagiotropis sp. & + & + \\
\hline & Pleurosigma sp. & + & + \\
\hline & Pseudonitzschia sp. & + & - \\
\hline & Rhizosolenia sp. & + & + \\
\hline & Skeletonema sp. & + & + \\
\hline & Striatella unipunctata (Lyngbye) C. Agardh 1932 & - & + \\
\hline & Thalassionema nitzschioides (Grunow) Mereschkowsky 1902 & + & - \\
\hline \multirow[t]{7}{*}{ Cyanobacteria } & Anabaena sp. & + & - \\
\hline & Chroococcus sp. & + & - \\
\hline & Lyngbya sp. & + & - \\
\hline & Merismopedia sp. & + & + \\
\hline & Microcystis sp. & - & + \\
\hline & Oscillatoria sp. & + & + \\
\hline & Pseudanabaena sp. & + & - \\
\hline \multirow[t]{26}{*}{ Dinoflagellates } & Alexandrium sp. & + & - \\
\hline & Amphidinium carterae Hulburt, 1957 & + & + \\
\hline & Biceratium furca (Ehrenberg) Vanhoeffen 1897 & + & + \\
\hline & Ceratium tripos (O.F.Müller) Nitzsch 1817 & + & + \\
\hline & Coolia monotis (Meunier 1919) & + & + \\
\hline & Gymnodinium sp. & + & + \\
\hline & Cyst of Karenia selliformis A.J.Haywood, K.A.Steidinger \& L.MacKenzie, 2004 & + & + \\
\hline & Cyst of Polykrikos & + & + \\
\hline & Ostreopsis siamensis (Schmidt 1901) & + & + \\
\hline & Peridinium sp. & + & + \\
\hline & Polykrikos sp. & + & + \\
\hline & Prorocentrum concavum (Fukuyo 1981) & + & + \\
\hline & Prorocentrum gracile (Schütt 1895) & + & - \\
\hline & Prorocentrum lima (Ehrenberg 1860) Dodge 1975 & + & + \\
\hline & Prorocentrum micans (Ehrenberg 1834) & + & + \\
\hline & Prorocentrum minimum (Pavillard 1916) Schiller 1931 & + & + \\
\hline & Prorocentrum rhathymum Loeblich III, Sherley et R.J. Schmidt 1979 & - & + \\
\hline & Prorocentrum triestinum (Schiller 1918) & + & + \\
\hline & Protoperidinium curtipes (Jørgensen 1912) Balech 1974 & + & + \\
\hline & Protoperidinium depressum (Bailey 1850) Balech 1974 & + & + \\
\hline & Protoperidinium divergens (Ehrenberg 1841) Balech 1974 & + & - \\
\hline & Protoperidinium mite (Pavillard 1916) Balech 1974 & - & + \\
\hline & Protoperidinium ovum (Schiller 1911) Balech 1974 & - & + \\
\hline & Protoperidinium steinii (Jørgensen 1899) Balech 1974 & + & - \\
\hline & Protoperidinium sp. & - & + \\
\hline & Scrippsiella sp. & + & - \\
\hline
\end{tabular}


Appendix 2. - Asymmetrical analysis of variance ANOVA of the abundances of microalgae major groups on leaves of $P$. oceanica at prospected stations. C, control stations; D, polluted station; C vs D, control vs disturbed; n.s., not significant.

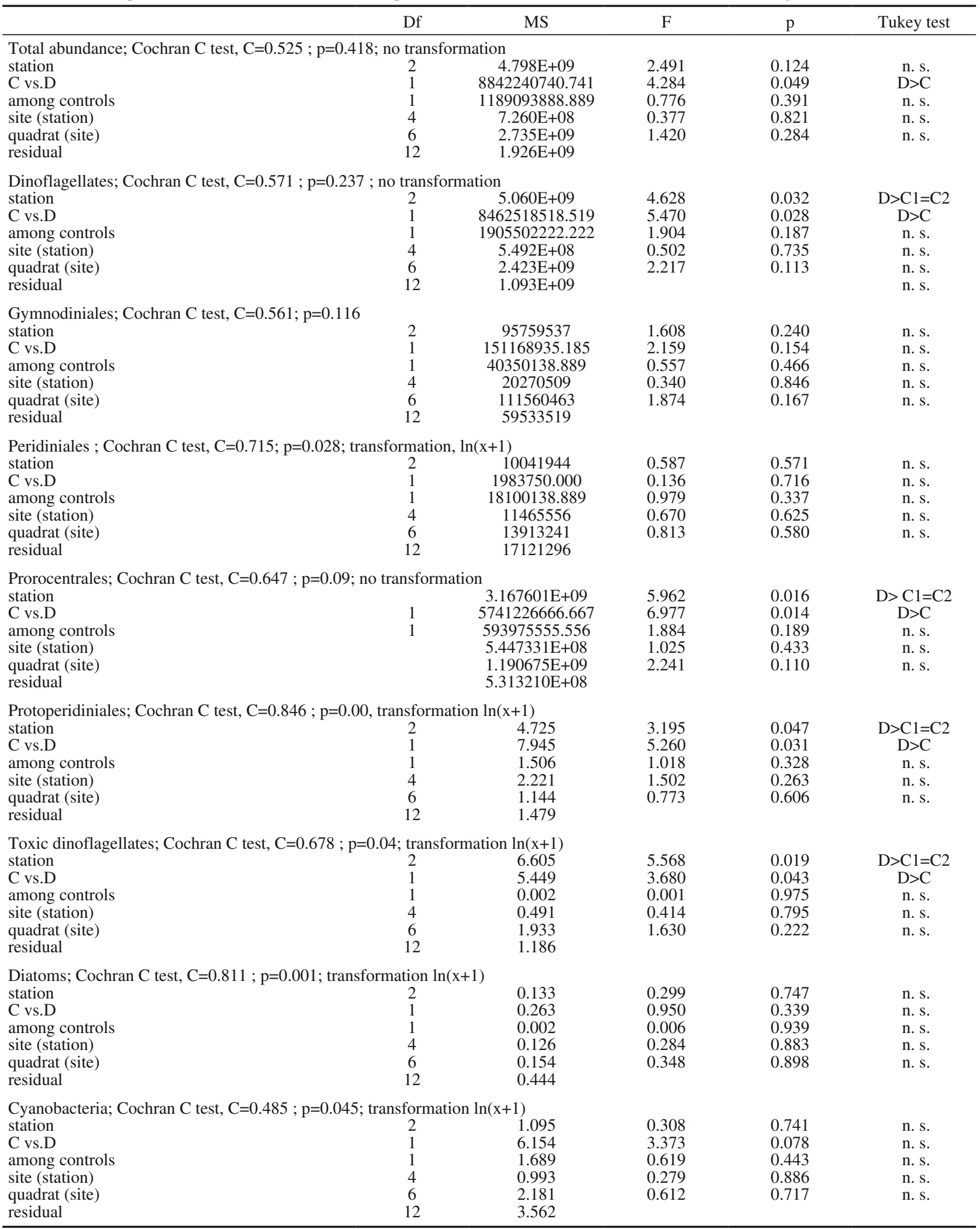

